prof. dr hab. inj. Jerzy Merkisz

Politechnika Poznańska

dr Wtodzimierz Stawecki, prof. IPS

Instytut Pojazdów Szynowych "TABOR"

\title{
Rail vehicles testing under RDE procedure
}

The paper addresses issues related to the ecological operation of rail transport vehicles. The evaluation of the vehicle environmental performance is based mainly on a comparison between the current state of the internal combustion engine (its emissions) with toxic pollutants emission limit values. These values are relevant in specific screening tests for vehicles or engines themselves. Legal emission regulations are of particular importance in the case of domestic operating conditions of rail vehicles due to the existence of a wide range of rolling stock (old and worn out vehicles among the new modern ones). Therefore, it becomes necessary to tackle the subject of how to assess the emission from rail vehicles engines in terms of their actual operating conditions according to the RDE (Real Driving Emission) procedure.

\section{Badania pojazdów szynowych według procedury RDE}

Referat dotyczy zagadnień zwiazanych z ekologicznym użytkowaniem pojazdów, wykorzystywanych $w$ transporcie szynowym. Ocena stopnia ekologiczności jest oparta w głównej mierze na porównaniu stanu bieżacego silnika spalinowego (jego emisyjności) z dopuszczalnymi wartościami emisji toksycznych zanieczyszczeń. Przedmiotowe wartości dotycza konkretnych testów badawczych pojazdów, czy też samych silników. W krajowych warunkach eksploatacji pojazdów szynowych emisyjne unormowania prawne nabieraja szczególnego znaczenia z uwagi na istnienie szerokiego spektrum taboru kolejowego (obok nowoczesnych występuja pojazdy bardzo wyeksploatowane). Konieczne staje się więc podjęcie tematyki dotyczqcej sposobu oceny emisyjności silników pojazdów szynowych w warunkach ich rzeczywistej eksploatacji wedtug procedury RDE (Real Driving Emission).

\section{WPROWADZENIE}

W okresie ostatnich kilkudziesięciu lat w krajach Unii Europejskiej (UE) wdrożono różne prawne instrumenty, mające na celu poprawę jakości powietrza atmosferycznego. Uzyskano to m.in. w wyniku kontrolowania emisji toksycznych zanieczyszczeń dla zdrowia człowieka i środowiska naturalnego. Dopuszczalne emisje składników gazowych spalin oraz cząstek stałych w UE ze względu na zaostrzane ograniczenia charakteryzują się coraz mniejszymi wartościami. Specyfika zmian taboru spalinowego dokonywana w warunkach krajowych wymaga nie tylko określania zgodności poziomu emisji zanieczyszczeń z silników spalinowych z normami, ale jednocześnie oceny stopnia ich ograniczania. Zmiana krajowego taboru spalinowego polega głównie na zastępowaniu wyeksploatowanych silników spalinowych - nowszymi (nie zawsze nowymi), naprawie głównej lub poddaniu ich remotoryzacji. Naprawa lub wymiana silnika spalinowego wiąże się zarówno z korzyściami ekonomicznymi oraz ekologicznymi. Stan techniczny krajowych, spalinowych pojazdów szynowych wymusza konieczność ich ciągłego monitorowania. $Z$ tego względu wymagana jest cykliczna ocena uciążliwości środowiskowej tych

\section{INTRODUCTION}

In the last few years the European Union (EU) implemented various legal instruments aimed at improving air quality. This is achieved, for example, through controlling emissions of pollutants harmful to human health and the environment. The permitted levels of exhaust gas components and particulates emissions in the EU, due to the continuously tightened restrictions, are characterized by increasingly lower values. The specificity of changes to the combustion engine vehicle fleet made domestically requires not only the determination of the internal combustion engines pollutant emissions level compliance with the standards, but also the assessment of the degree of their reduction. Changing the national fleet of combustion engine vehicles mainly consists of replacing wornout combustion engines with newer ones (not necessarily new ones), vehicle overhaul, or remotorization. Overhaul and remotorization of the internal combustion engine is associated with both environmental and economic benefits. The technical condition of the domestic internal combustion rail vehicles forces the need for their continued monitoring. The regular assessment of their environmental impact in real traffic 
pojazdów w rzeczywistych warunkach ruchu (RDE Real Driving Emission).

Mimo niewielkiego udziału pojazdów szynowych w całkowitej emisji szkodliwych składników w spalinach emitowanych przez środki transportu, wytyczane są kolejne cele pozwalające na ograniczenie uciążliwości środowiskowej rozpatrywanego rodzaju transportu. Określono więc cele dotyczące przede wszystkim ochrony klimatu (ograniczenia w emisji dwutlenku węgla), ograniczenia energochłonności ruchu oraz redukcji emisji składników toksycznych spalin.

Prace w zakresie transportu masowego (samochodowego i kolejowego) prowadzone $\mathrm{w}$ ostatnich latach zwracają zatem szczególną uwagę na ograniczenie jego szkodliwego oddziaływania na środowisko naturalne człowieka - emisję toksycznych zanieczyszczeń w spalinach. Obecnie najpopularniejszymi sposobami na zmniejszenie emisji substancji toksycznych w transporcie kolejowym są m.in.:

- modernizacja taboru kolejowego,

- zastosowanie napędów i/lub paliw alternatywnych,

- zastosowanie pojazdów specjalnych (szynowodrogowych),

- zastosowanie układów oczyszczania spalin w nowych silnikach/pojazdach i tych już dotąd użytkowanych (tzw. retrofitting).

Minimalizacja udziału substancji toksycznych w emitowanych przez silniki spalinach, jest procesem stałym i wymaga wspomnianych nowoczesnych układów oczyszczania spalin. Pożądane jest stosowanie coraz doskonalszych oraz efektywniejszych konstrukcji, które zapewnią dużą skuteczność ograniczania zanieczyszczeń w gazach wylotowych. Obecnie zmniejszenie emisji szkodliwych produktów niezupełnego i niecałkowitego spalania paliwa w tłokowych silnikach spalinowych może być osiagnięte przez realizację dwóch typów przedsięwzięć. Można je określić jako tzw. wewnątrzsilnikowe i pozasilnikowe. Pierwsze z nich polegają na wprowadzeniu zmian konstrukcyjnych lub regulacyjnych $w$ podzespołach i układach silnika, powodujących, że spaliny opuszczające cylindry zawieraja mniej substancji szkodliwych. W ramach drugich przedsięwzięć w układach wylotowych silników instaluje się specjalne systemy oczyszczania spalin, w tym reaktory katalityczne: trójfunkcyjne (TWC - Three Way Catalyst), reaktory utleniające (DOC-Diesel

Oxidation Catalyst) oraz układy selektywnej redukcji katalitycznej (SCR - Selective Catalytic Reduction).

Nowoczesne technologie w zakresie pozasilnikowych sposobów oczyszczania spalin są wykorzystywane nie tylko w nowo produkowanych pojazdach, lecz także w tych już użytkowanych. Ma to miejsce przy retrofittingu, czyli montażu w układach wylotowych ww. zaawansowanych technicznie układów oczyszczania spalin. Skutkuje to m.in. spełnianiem nowszej normy operating conditions (RDE - Real Driving Emission) is, therefore, required.

Despite the small share of rail vehicles in the total vehicle emissions of harmful exhaust gas components, new targets for the environmental impact reduction of this type of transportation are set regularly. Thus goals related primarily to climate protection (restrictions on carbon dioxide emissions), reducing the energy consumption of traffic and the reduction of toxic emissions have been set.

As a result the development efforts for mass transport (road and rail) conducted in recent years pay particular attention to reducing its harmful effects on the natural environment -toxic pollutants emission in the exhaust gas. Currently, the most popular methods of toxic substances emissions reduction in rail transport are for example:

$$
\begin{aligned}
& \text { - } \quad \text { rail vehicle fleet modernization, } \\
& \text { - } \quad \text { use of alternative drives and fuels, } \\
& \text { use of aftertreatment technologies in }
\end{aligned}
$$
new engines/vehicles, as well as those already in operation (retrofitting).

Minimizing the share of toxic substances in the exhaust gases emitted by combustion engines is an ongoing process and requires these advanced exhaust aftertreatment systems. It is desirable to use increasingly sophisticated and efficient structures, which will ensure high efficiency of exhaust pollutants reduction. The harmful products emissions reduction of incomplete and partial fuel combustion in reciprocating internal combustion engines can be achieved using two methods. These can be described as engine and exhaust aftertreatment solutions. The first ones rely on introducing structural changes or regulatory changes in engine components and systems, causing the exhaust gases leaving the cylinders to contain fewer harmful substances. As a part of the latter solutions special exhaust gas aftertreatment systems are installed in the engine exhaust, including trifunctional catalytic converters (TWC - Three Way Catalyst) oxidation catalysts (DOC - Diesel Oxidation Catalyst) and selective catalytic reduction systems (SCR - Selective Catalytic Reduction) .

Modern technologies for exhaust gas aftertreatment methods are used not only in newly manufactured vehicles, but also in those already in operation. This is called retrofitting, where the technologically advanced exhaust aftertreatment systems are installed in vehicle exhaust systems. As a result vehicles equipped with such systems can meet newer exhaust emission standards. These modernization measures are justified and cost effective both in the case of heavy road vehicles (such as lorries, buses and coaches), as well as in the case of heavy rail vehicles with combustion engines, which have a high unit emission of carbon monoxide, hydrocarbons, nitrogen oxides and particulate matter. 
emisji zanieczyszczeń w spalinach przez pojazdy wyposażone $\mathrm{w}$ takie układy. Przedmiotowe działania modernizacyjne są zasadne i opłacalne zarówno w przypadku ciężkich pojazdów drogowych (np. samochodów ciężarowych, autobusów i autokarów), jak również w przypadku ciężkich pojazdów szynowych trakcji spalinowej, które emitują jednostkowo dużo tlenku węgla, węglowodorów, tlenków azotu i cząstek stałych

\section{BADANIA W WARUNKACH RZECZYWI- STYCH}

\subsection{Uwagi wstępne}

Jedną z zalet stanowiskowych badań emisji spalin wykonywanych w laboratoriach jest ich powtarzalność w niezmiennych warunkach (w ramach dopuszczalnej dokładności). Prowadzi się je według ściśle określonego przez ustawodawców schematu (cyklu badawczego). W przypadku badań na hamowniach podwoziowych cykle badawcze zawierają pewne wybrane szybkości, z jakimi porusza się pojazd w ruchu miejskim oraz pozamiejskim (np. test NEDC w Europie). Natomiast $\mathrm{w}$ przypadku badań na hamowniach silnikowych określone parametry emisyjne mierzy się $\mathrm{w}$ wybranych punktach pracy silnika (np. testy WHSC i WHTC). Stąd prowadząc badania emisji spalin w określonych warunkach laboratoryjnych, nie da się nigdy w pełni odzwierciedlić warunków panujących w rzeczywistej eksploatacji pojazdów. Jest to tylko ich przybliżenie, co jest główną wadą badań stanowiskowych.

Obecny stopień zaawansowania techniki i technologii $\mathrm{w}$ wielu dziedzinach przemysłu, $\mathrm{w}$ tym również $\mathrm{w}$ przemyśle motoryzacyjnym, powoduje wzrost wymagań w zakresie produkcji urząazeń służących do pomiarów emisji zanieczyszczeń $w$ spalinach wszelkich środków transportu. Aby te wymagania mogły być spełniane w stopniu odpowiednim do zmieniających się okresowo przepisów konieczna stała się koncentracja wytwórców sprzętu badawczego w tej dziedzinie. Badania emisji toksycznych składników spalin są procesem skomplikowanym. Obecnie funkcjonujące analizatory do pomiaru emisji wymagają szczególnych warunków laboratoryjnych, a procedury homologacyjne obejmują testy na hamowniach silnikowych i podwoziowych, które jednak (jak już wspomniano) nie odzwierciedlaja $\mathrm{w}$ pełni emisji $\mathrm{w}$ rzeczywistych warunkach eksploatacji. Najnowsze wyniki badań prowadzonych w warunkach rzeczywistych ukazują, że w przypadku niektórych składników toksycznych spalin emisja ta jest większa nawet o kilkaset procent. W związku z tym coraz bardziej dostrzegalny jest trend co do usankcjonowania pomiaru emisji zanieczyszczeń w spalinach w warunkach rzeczywistego ruchu pojazdów - postuluje się wprowadzenie tego typu pomiarów do europejskich działań legislacyjnych (rys. 1) [9].

\section{TESTS IN REAL OPERATING CONDITIONS}

\subsection{Preliminary remarks}

One of the advantages of the aforementioned stationary exhaust emission tests performed in laboratories is their repeatability in consistent conditions (within the allowable accuracy). These tests are carried out according to a scheme strictly defined by legislators (test cycle). For research on chassis dynamometers the test cycles contain certain selected speed with which the vehicle is traveling in urban and rural conditions (e.g. the European NEDC test). However, in the case of testing on engine dynos the set emission parameters are measured in the selected operating points (e.g. WHSC and WHTC tests). Hence emission testing under certain laboratory conditions can never fully reflect the vehicle's real operating conditions. This is only an approximation thereof, which is a major disadvantage in stationary tests.

The current state of technology in many industries, including the automotive industry, increases the requirements for the production of exhaust emission measurement devices for all means of transport. For these requirements to be met to an appropriate extent with the periodically changing regulations it became necessary for the manufacturers of test equipment to cooperate. Testing toxic exhaust emissions is a complex process. The existing analyzers for emission measurements require specific laboratory conditions, and type approval procedures include engine and chassis dyno tests, which (as already mentioned) do not fully reflect the emissions under real operating conditions. The latest results of research carried out in real driving conditions show that in the case of certain toxic exhaust components the emissions can be up to several hundred percent higher. Therefore, there is an increasingly visible trend to sanction the exhaust emission measurements in real driving conditions - there are calls for the introduction of this type of measurement to the European legislative action (Fig. 1) [9].

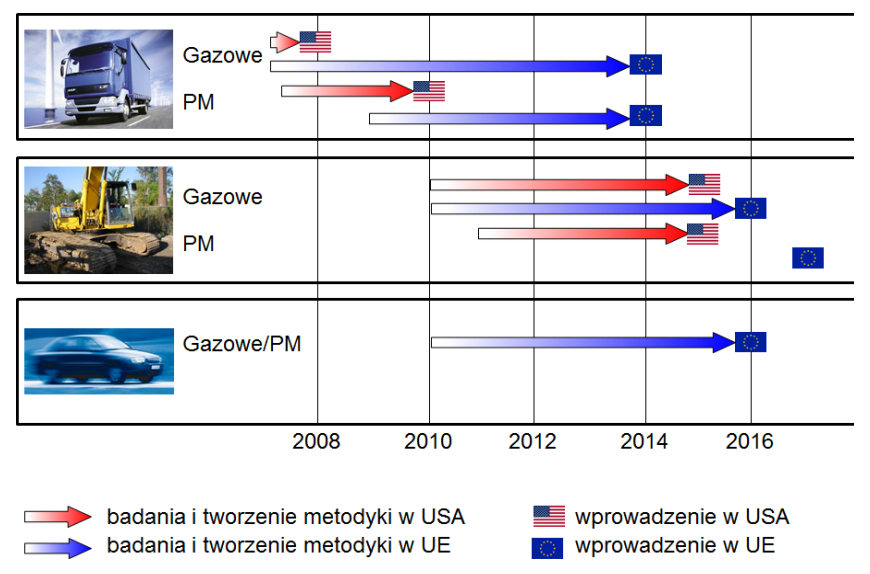

Rys. 1. Dokonane i przewidywane wprowadzenie pomiarów drogowych emisji zanieczyszczeń w spalinach do procedur homologacyjnych pojazdów [9] 
Jazdy testowe w trakcie badań drogowych wykonuje się np. na odcinkach o długości od kilku do kilkudziesięciu kilometrów w różnych warunkach drogowych m.in. różne natężenie ruchu (ruch miejski, pozamiejski, autostradowy). Największą niedogodnością takich badań jest jednak koszt aparatury pomiarowej i jej przystosowanie do warunków zabudowy w pojeździe. Zyskuje się natomiast wiarygodne wyniki pomiarów, niemożliwe do uzyskania $\mathrm{w}$ warunkach laboratoryjnych na hamowniach.

Jak już wspomniano ocena ekologiczności oparta jest w większości przypadków na porównaniu stanu bieżącego silnika spalinowego (jego emisyjności) z wartościami dopuszczalnymi emisji składników szkodliwych w spalinach. Wartości te dotyczą konkretnych testów badawczych silników lub pojazdów, o których mowa była wcześniej. W warunkach eksploatacji pojazdów szynowych w Polsce wymagania te nabierają nieco odmiennego kształtu, gdyż posiadanie szerokiego spektrum taboru kolejowego znacząco zmienia obraz ekologiczności tego typu pojazdów. Konieczne staje się więc podjęcie prac dla dokonania oceny emisji zanieczyszczeń z silników spalinowych pojazdów trakcyjnych, podobnie jak drogowych, także w warunkach ich rzeczywistej eksploatacji. Zatem wszystkie działania mające na celu ocenę rzeczywistego stopnia emisyjności spalinowych pojazdów szynowych oraz próby ich poprawy są uzasadnione.

\subsection{Przykładowe badania $w$ rzeczywistych warun- kach ruchu}

Na podstawie przeprowadzonych badań w warunkach rzeczywistej eksploatacji różnego rodzaju pojazdów transportu masowego dokonano oceny uciążliwości środowiskowej tych pojazdów i wskazano udział szynowych środków transportu w emisji zanieczyszczeń. Badaniom poddano różne typy pojazdów szynowych (m.in. lokomotywa spalinowa i lekki pojazd szynowy) oraz pojazdów drogowych (samochód dostawczy, ciężarowy oraz autobus miejski). Wyboru dokonano w taki sposób, aby uwzględnić przedstawicieli transportu osobowego oraz towarowego (rys. 2). W tabeli 1 przedstawiono podstawowe dane techniczne badanych pojazdów. Wybrane pojazdy obejmują szerokie spektrum środków transportu o zróżnicowanych parametrach m.in. objętościach skokowych silnika i mocach użytecznych. Różnorodność taka ma na celu uzyskanie odpowiedzi na pytanie o wielkość oddziaływania tych pojazdów na środowisko oraz o różnice między uzyskanymi wynikami.

Poziom odniesienia emisji poszczególnych toksycznych składników spalin (tlenku węgla, węglowodorów i tlenków azotu) określono w wyniku badań emisji zanieczyszczeń na oporniku wodnym lub w warunkach jazdy wszystkich pojazdów szynowych. Dodatkowo wykonano badania drogowe emisji zanieczyszczeń dla pojazdów samochodowych. Wyniki przepro-
Fig. 1 - The introduced and anticipated changes to the driving exhaust gas emissions measuring procedures for the vehicle type approval tests [9]

The drive during the road tests cycles is carried out on the lengths of several to tens of kilometers in different road conditions - including various traffic conditions (urban, suburban, motorway). The biggest disadvantage of such research, however, is the cost of the measurement equipment and its preparation for installation on the vehicle. The main advantage is the reliability of measurement results that is impossible to obtain in the laboratory tests on stationary engine and chassis dynamometers.

As mentioned previously the environmental assessment is based mostly on a comparison of the current state of the internal combustion engine (its emissivity) with the emission limit values of harmful exhaust gas components. These values apply to specific tests for engines or vehicles as described before. In the case of operating conditions of rail vehicles in Poland, these requirements take on a slightly different shape, as having a wide and diverse range of rolling stock significantly changes the perceived environmental performance of vehicles of this type. So it becomes necessary to undertake the work of evaluating emissions from internal combustion engines of rail vehicles, like for the road vehicles, even in real operating conditions. Thus, any measures aimed at assessing the actual degree of exhaust emission of rail vehicles and efforts to improve these values can be considered necessary and justified.

\subsection{Przykładowe badania $w$ rzeczywistych warun- kach ruchu}

Based on the results of tests in real operating conditions of various kinds of mass transportation vehicles the environmental impact of these vehicles was assessed and the share of emissions in rail transport was indicated. The study examined several different types of rail vehicles (including a diesel locomotive and a light rail vehicle) and road vehicles (a van, a truck and a city bus). The selection was made in such a way to include vehicles representative of passenger transport and freight (Fig. 2). Table 1 shows the basic specifications of the tested vehicles. The vehicles include a wide spectrum of means of transport with different parameters, such as: engine displacements or net power. This diversity is expected to answer the question of the environmental impact of these vehicles and on the difference between the results obtained.

The baseline emissions of various toxic exhaust components (carbon monoxide, hydrocarbons and nitrogen oxides) was determined as a result of pollutant emission testing on a water resistor or in driving conditions of rail vehicles. Additionally, a study of emissions was performed for automotive vehicles. Results of this study indicate a significant degree of exploitation of the large and heavy diesel 
wadzonych badań wskazują na znaczny stopień wyeksploatowania dużej i ciężkiej lokomotywy spalinowej (duże wartości emisji jednostkowej $\mathrm{CO}$ i $\mathrm{NO}_{x}$; rys. 3). Analiza emisji zanieczyszczeń przez jeden z badanych pojazdów drogowych - autobus miejski wskazuje również na duże wartości emisji jednostkowej tlenków azotu. Należy wziąć pod uwagę to, że testy, na podstawie których przeprowadza się te badania są zróżnicowane, lecz nie mniej jednak służą one do określenia typowych wielkości emisji zanieczyszczeń dla poszczególnych reprezentantów środków transportu. Z tego powodu zestawiono je ze sobą, co pozwala na stwierdzenie skali emisji poszczególnych toksycznych składników spalin. locomotive (large values of $\mathrm{CO}$ and NOx emission; Fig. 3). The analysis of one of the vehicle's emissions - the city bus also shows high values of nitrogen oxides emission. It should be considered that the tests that are the basis for the carried out studies are diverse, but nevertheless they are used to determine the typical emissions for individual representatives of different transport means. Hence they have been displayed together, allowing for determining the amounts of individual emissions of toxic exhaust components.

a)

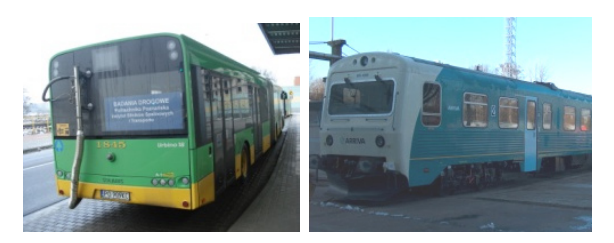

b)
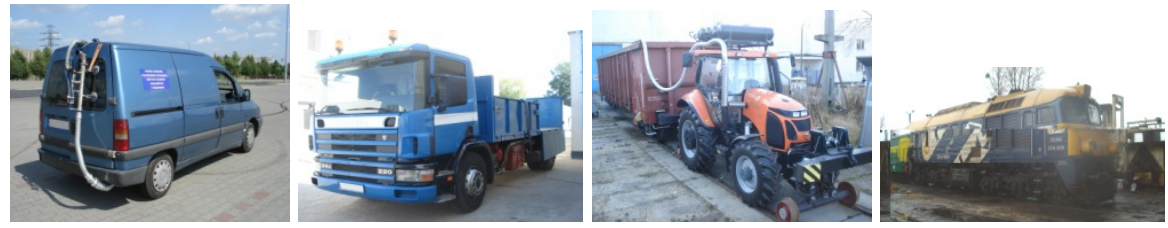

Rys. 2. Pojazdy poddawane badaniom w warunkach rzeczywistej eksploatacji: a) przeznaczone do przewozów pasażerskich, b) przeznaczone do przewozów towarowych

Fig. 2 - Vehicles tested in real driving conditions: a) for passenger transport, b) for freight

\begin{tabular}{|c|c|c|c|c|c|}
\hline Pojazd & Typ silnika & $\begin{array}{c}\mathrm{V}_{\mathrm{ss}} \\
{\left[\mathrm{dm}^{3}\right]}\end{array}$ & $\begin{array}{c}\text { Układ i liczba } \\
\text { cylindrów }\end{array}$ & $\begin{array}{c}\mathrm{N}_{\mathrm{e}} \\
{[\mathrm{kW}]}\end{array}$ & $\begin{array}{c}\mathrm{n}_{\mathrm{Ne}-\max } \\
{[\mathrm{obr} /} \\
\min ]\end{array}$ \\
\hline \multicolumn{6}{|c|}{ Przewozy pasażerskie } \\
\hline $\begin{array}{c}\text { Solaris } \\
\text { Urbino } 18\end{array}$ & $\begin{array}{c}\text { DAF PR } \\
228\end{array}$ & 9,2 & R6 & 266 & 1900 \\
\hline $\begin{array}{c}\text { Dwuczło- } \\
\text { nowy } \\
\text { zespół } \\
\text { trakcyjny } \\
\text { MR/MRD }\end{array}$ & F12L413F & 19,1 & $\mathrm{~V} 12\left(90^{\circ}\right)$ & $\begin{array}{l}2 \times \\
239\end{array}$ & 2160 \\
\hline \multicolumn{6}{|c|}{ Przewozy towarowe } \\
\hline $\begin{array}{c}\text { Peugeot } \\
\text { Expert }\end{array}$ & $\begin{array}{c}\text { Peugeot } \\
1,9 \text { TD }\end{array}$ & 1,9 & R4 & 68 & 4000 \\
\hline Scania 94G & $\begin{array}{c}\text { DSC 9 } \\
\text { turbo }\end{array}$ & 9,0 & R6 & 162 & 2000 \\
\hline $\begin{array}{c}\text { Ciagnik } \\
\text { szynowo- } \\
\text { kołowy } \\
\text { Orion } \\
\text { Crystal } 13\end{array}$ & Deutz & 6,8 & $\mathrm{R} 4$ & 98 & 2200 \\
\hline $\begin{array}{l}\text { Lokomo- } \\
\text { tywa ST44 }\end{array}$ & $14 \mathrm{D} 40$ & 150,6 & $\mathrm{~V} 12\left(45^{\circ}\right)$ & 1470 & 750 \\
\hline
\end{tabular}

\begin{tabular}{|c|c|c|c|c|c|}
\hline Vehicle & Engine type & $\begin{array}{c}\mathrm{V}_{\mathrm{ss}} \\
{\left[\mathrm{dm}^{3}\right]}\end{array}$ & $\begin{array}{c}\text { Cylinder } \\
\text { numer and } \\
\text { configuration }\end{array}$ & $\begin{array}{c}\mathrm{N}_{\mathrm{e}} \\
{[\mathrm{kW}]}\end{array}$ & $\begin{array}{l}\mathrm{n}_{\mathrm{Ne}-\max } \\
{[\mathrm{rpm}]}\end{array}$ \\
\hline \multicolumn{6}{|c|}{ Passenger transport } \\
\hline $\begin{array}{c}\text { Solaris Urbino } \\
18\end{array}$ & DAF PR 228 & 9,2 & R6 & 266 & 1900 \\
\hline $\begin{array}{l}\text { Diesel multiple } \\
\text { unit MR/MRD }\end{array}$ & F12L413F & 19,1 & $\mathrm{~V} 12\left(90^{\circ}\right)$ & $2 \times 239$ & 2160 \\
\hline \multicolumn{6}{|c|}{ Freight } \\
\hline Peugeot Expert & $\begin{array}{c}\text { Peugeot } 1,9 \\
\text { TD }\end{array}$ & 1,9 & R4 & 68 & 4000 \\
\hline Scania 94G & DSC 9 turbo & 9,0 & R6 & 162 & 2000 \\
\hline $\begin{array}{l}\text { Road-rail } \\
\text { tractor Orion } \\
\text { Crystal } 13\end{array}$ & Deutz & 6,8 & R4 & 98 & 2200 \\
\hline $\begin{array}{l}\text { ST44 locomo- } \\
\text { tive }\end{array}$ & $14 \mathrm{D} 40$ & 150,6 & $\mathrm{~V} 12\left(45^{\circ}\right)$ & 1470 & 750 \\
\hline
\end{tabular}

Szczególowe dane techniczne silników stosowanych w pojazdach drogowych i szynowych $[2,3,8]$

Tabela 1

Table 1 - Detailed technical data on engines used in road and rail vehicles $[2,3,8]$ 


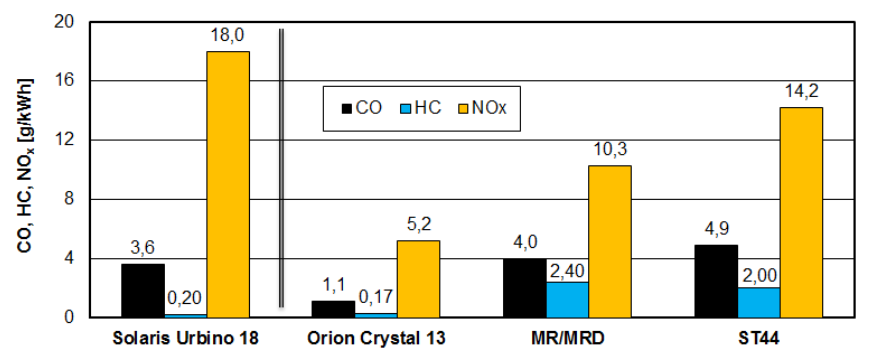

Rys. 3. Emisja jednostkowa składników toksycznych spalin z badanego autobusu miejskiego i pojazdów szynowych

Fig. 3 - Specific emission of toxic fumes from the tested urban bus and rail vehicles

Badania zawartości zanieczyszczeń gazowych w spalinach prowadzono $\mathrm{w}$ aspekcie wyznaczania ich nateżenia emisji. W przypadku pojazdów samochodowych badań takich dokonano w warunkach drogowych. Samochód dostawczy Peugeot Expert badano m.in. w warunkach ruchu miejskiego, pozamiejskiego i autostradowego na terenie aglomeracji poznańskiej [6]. Badania pojazdu ciężarowego marki Scania prowadzono na trasach miejskich i pozamiejskich (PoznańWrześnia-Poznań) [7], natomiast badania autobusu miejskiego na typowych liniach komunikacyjnych w Poznaniu [5]. We wszystkich przypadkach wyznaczono średnią wartość natężenia emisji toksycznych składników spalin.

Badania lokomotywy spalinowej ST44 prowadzono w warunkach badań emisji zanieczyszczeń w spalinach na opornikach wodnych. Określenie wskaźników ekologicznych dla spalinowych zespołów trakcyjnych (szynobus MR/MRD) wymagało pomiarów emisji składników szkodliwych podczas jazdy, ze względu na wyposażenie tych pojazdów w przekładnię hydrauliczną. W takim przypadku nie ma możliwości odbioru mocy z silnika na postoju (brak możliwości wykorzystania hamulca wodnego lub elektrycznego). $Z$ tego też powodu badania emisji składników toksycznych przeprowadzono podczas ruchu $\mathrm{z}$ włączoną funkcją podhamowania. Badania ciagnika szynowego wykonane zostały w Instytucie Pojazdów Szynowych „Tabor" w Poznaniu (na torze kolejowym w warunkach ruchowych).

Największe wartości natężenia emisji toksycznych składników spalin dla drogowych pojazdów transportu masowego (rys. 4) uzyskano w przypadku autobusu Solaris Urbino 18, wyposażonego w silnik ZS o największej objętości skokowej spośród badanych pojazdów. Należy zauważyć brak jednoznacznej tendencji w natężeniu emisji toksycznych składników spalin, co może wynikać m.in. z zastosowanych układów oczyszczania spalin w tych pojazdach lub ich braku (Scania 94G). Podobne działania prowadzono w przypadku pojazdów szynowych. Największe wartości natężenia emisji toksycznych gazowych składników spalin z pojazdów szynowych (rys. 5) odnotowano dla typowej lokomotywy spalinowej ST44.

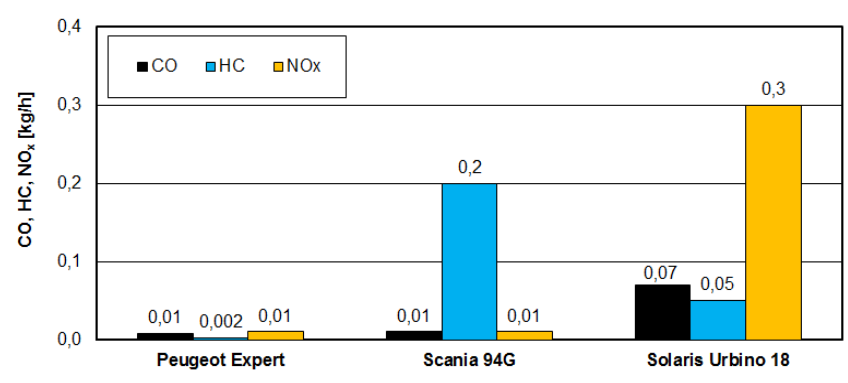

Rys. 4. Natężenie emisji toksycznych składników spalin z drogowych pojazdów transportu masowego

Fig. 4 - The toxic exhaust emission intensity from mass transport road vehicles

Exhaust gas content research was carried out in the context of determining the pollutant emission concentration. In the case of cars such studies were made in driving conditions. The Peugeot Expert van was tested in urban, suburban and motorway traffic within the Poznan agglomeration [6]. The testing of Scania truck was carried out on urban and motorway routes (Poznan-Wrzesnia-Poznan) [7], while the bus tests were performed on typical municipal communication lanes in Poznan [5]. In all cases, the average concentration of toxic exhaust emissions was determined.

Emission tests of ST44 diesel locomotive were carried out on water resistors. Determination of environmental indicators for diesel multiple units (railcar $\mathrm{MR} / \mathrm{MRD}$ ) required emission measurements of harmful exhaust components while driving, due to those vehicles being equipped with a hydraulic transmission. In this case, there is no possibility of receiving power from the engine when stationary (no option of using water or electric resistors). For this reason, studies of toxic emissions were carried out during movement braking enabled. Research of the road-rail tractor was made at the Rail Vehicles Institute "TABOR" in Poznan (on the railway track in real operating conditions).

The highest values of toxic exhaust emissions concentration in road mass transport vehicles (Fig. 4) was obtained for the Solaris Urbino 18 bus, which was equipped with a diesel engine with the largest displacement of all the tested vehicles. Note the lack of a clear trend in the concentration of toxic exhaust emissions, which may be due to the exhaust aftertreatment systems used in these vehicles or their absence (Scania 94G). Similar steps were taken in the case of rail vehicles. The largest concentration of toxic gaseous exhaust emission components among rail vehicles (Fig. 5) was recorded for a typical diesel locomotive ST44.

In order to determine the environmental impact of all tested vehicles the research was carried out considering the number of passengers or the weight of cargo (for freight transport means). In the first case it is assumed that the concentration of toxic exhaust component expressed in $\mathrm{kg} / \mathrm{h}$ will be determined in one hour period and be counted per passenger. This 
W celu określenia wpływu wszystkich pojazdów na środowisko dokonano badań $\mathrm{w}$ aspekcie liczby przewożonych pasażerów lub masy przewożonego ładunku (w przypadku transportu towarowego). W pierwszym przypadku przyjęto, że natężenie emisji danego toksycznego składnika spalin wyrażane $\mathrm{w} \mathrm{kg} / \mathrm{h}$ zostanie określone w ciagu jednej godziny i będzie przypadało na jednego pasażera. Pozwoli to na ocenę oddziaływania danych środków transportu na środowisko naturalne człowieka w postaci określonej emisji poszczególnych składników spalin. Uwzględnieniu podlegać będzie również objętość skokowa silnika spalinowego, gdyż wynik nie uwzględnia mocy silnika, a jedynie jego godzinową emisję. Z przeprowadzonej analizy wynika, że badane środki transportu pasażerskiego (autobus miejski i szynowy) w przeliczeniu na jedną godzinę eksploatacji na jednego pasażera uzyskują podobne wyniki - zaobserwować można zbliżone wartości emisji określonej dla wszystkich analizowanych szkodliwych składników spalin (rys. 6).

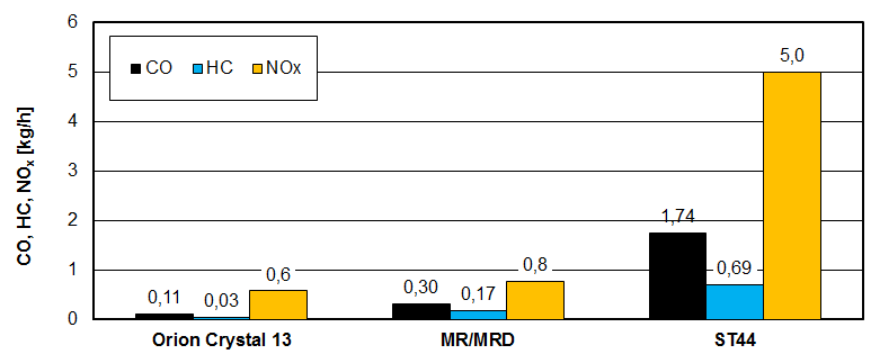

Rys. 5. Natężenie godzinowej emisji szkodliwych składników spalin $\mathrm{z}$ badanych pojazdów szynowych

Fig. 5 - The hourly emissions intensity of harmful components from tested rail vehicles

Podobnych analiz jak w punkcie poprzednim, dokonano $\mathrm{w}$ odniesieniu do przejazdów towarowych. Analizę wykonano przy założeniu, że masa pełnego wagonu towarowego to $80 \mathrm{Mg}$. Siła uciagowa analizowanych pojazdów (ciagnik szynowy, lokomotywa ST44) to odpowiednio: 4 i 10 wagonów. Dopuszczalna ładowność samochodu dostawczego to $0,8 \mathrm{Mg}$, natomiast zabudowy typu wywrotka pojazdu ciężarowego - $9 \mathrm{Mg}$. Z rysunku 7 wynika, że emisja poszczególnych toksycznych składników spalin jest najmniejsza dla ciagnika szynowego. Biorąc pod uwagę niewielką wartość emisji jednostkowej i natężenia emisji zanieczyszczeń tego pojazdu (rys. 3 i 5) przy jednocześnie niezbyt dużym uciagu deklarowanym przez producenta, wartości emisji tlenku węgla przypadającego na tonę ładunku są zdecydowanie najmniejsze. W przypadku samochodu ciężarowego Scania $94 \mathrm{G}$ uzyskano wartość emisji tlenku węgla 3,5-krotnie większą. Duża emisja tlenków azotu wynika $\mathrm{z}$ dużego wysilenia pojazdów i dość przestarzałych systemów wtryskowych (uwaga ta dotyczy szczególnie lokomotywy spalinowej). Dla ciagnika szynowego i samochodu ciężarowego uzyskano wartości około 5-krotnie mniejsze w zakresie emisji tlenków azotu w stosunku do lokomotywy spalinowej ST44. will allow an assessment of the environmental impact of the means of transport in the form of emission assessment of individual components. The displacement of the internal combustion engine will also be considered, because the result does not take into account the power of the engine, only the hourly emissions. The analysis shows that the tested means of passenger transport (bus and rail) obtain similar results per one hour of operation per passenger - similar emission values of all analyzed harmful exhaust components can be observed (Fig. 6).

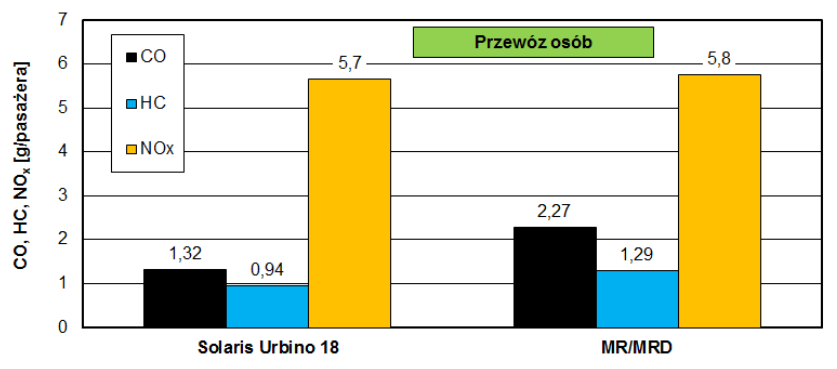

Rys. 6. Porównanie emisji toksycznych składników spalin przypadającej na jednego pasażera podczas 1-godzinnego użytkowania pojazdu drogowego i szynowego

Fig. 6 - Comparison of toxic exhaust emissions per one passenger during 1 hour of operation of the road and rail vehicles

Similar analysis as in the preceding paragraph has been made for means of cargo transport. The analysis is performed with the assumption that the full weight of the freight wagon is $80 \mathrm{Mg}$. The lugging force of the analyzed vehicles (road-rail tractor and ST44 locomotive) are 4 and 10 wagons respectively. Payload of commercial vehicles is $0.8 \mathrm{Mg}$, whereas a building tipper vehicle $-9 \mathrm{Mg}$. Figure 11 shows that emissions of various toxic components of exhaust gas are the lowest for the road-rail tractor. Given the small value of the specific emission and the vehicle emission concentration (Fig. 3 and 5) along with not too large lugging force indicated by the manufacturer, the carbon monoxide emissions per a ton of cargo are by far the smallest. The obtained value of carbon monoxide 3.5 times greater was obtained for Scania $94 \mathrm{G}$ truck. The high emission of nitrogen oxides is due to the high load and outdated injection systems (this applies especially to the diesel locomotive). The values of NOx emissions obtained for the road-rail tractor and the truck were about 5 times smaller than for the diesel locomotive ST44.

Based on the presented results of studies conducted in real operating conditions (a new direction in the study of pollutant emissions in the exhaust gases), it is clear that rail vehicles are a fully competitive mode of transport for passengers or cargo compared to road vehicles in terms of emission of toxic exhaust components as counted per one passenger or one ton of cargo transported. 
$\mathrm{Na}$ podstawie zaprezentowanych wyników badań, przeprowadzonych w warunkach rzeczywistej eksploatacji (nowy kierunek w badaniach emisji zanieczyszczeń w spalinach), należy stwierdzić, że pojazdy szynowe w zakresie przewozu osób lub ładunków są w pełni konkurencyjnym środkiem transportu w stosun$\mathrm{ku}$ do pojazdów drogowych pod względem emisji toksycznych składników spalin odniesionej do jednego pasażera lub jednej tony transportowanego ładunku.

\section{PODSUMOWANIE}

Do oceny ekologicznej pojazdów najbardziej pożądane są badania drogowe (rzeczywiste warunki ruchu/eksploatacji), gdyż tylko wtedy można uzyskać informację o rzeczywistej emisji substancji szkodliwych z pojazdów. Pomiary certyfikacyjne (homologacyjne) pojazdów transportu masowego przeprowadzane na hamowniach silnikowych dotyczą samego silnika i niestety nie przedstawiają żadnej informacji o emisji i zużyciu paliwa podczas rzeczywistych warunków ruchu pojazdu nim napędzanego [4]. Wykorzystanie mobilnych analizatorów spalin spowodowało zwiększenie zainteresowania pomiarami emisji podczas rzeczywistych warunków ruchu pojazdów, zwłaszcza ciężkich, użytkowych [1]. Analiza własna przeprowadzone badania - oraz światowych trendów w dziedzinie ekologii wskazuje, że w celu efektywnego obniżenia zanieczyszczenia środowiska naturalnego, konieczny jest pomiar emisji toksycznych gazów spalinowych właśnie w warunkach rzeczywistych.

Jak już wspomniano badania drogowe pojazdów w rzeczywistych warunkach ruchu są bardziej korzystne z punktu widzenia ekologii eksploatacji pojazdów. Pozwalają one na pomiary emisji substancji szkodliwych w różnych warunkach, a nie tylko w warunkach ściśle określonych, jak w przypadku badań stanowiskowych. Daje to konstruktorom więcej informacji na temat tego, w jakim kierunku powinny iść prace prowadzące m.in. do optymalizacji właściwości ekologicznych silników.

Badania pojazdów w warunkach ruchu rzeczywistego są możliwe dzięki nowoczesnej aparaturze badawczej. Aparatura ta musi mieć zwartą budowę, aby istniała możliwość zamontowania jej w pojeździe. Musi być też uniwersalna by móc wykorzystywać ją do pomiarów stężeń substancji szkodliwych w spalinach pojazdów transportu masowego różnego rodzaju i dodatkowo różnej kategorii homologacyjnej.

Istnieją obiektywne przesłanki, że w niedalekiej przyszłości, z uwagi na wyraźny postęp techniczny w zakresie pomiaru emisji szkodliwych składników spalin w ruchu rzeczywistym, badania emisji spalin zarówno w zakresie zgodności pojazdów w odniesieniu do homologacji typu, jak i poziomu emisyjności pojazdów już eksploatowanych, będą wymagać pozyskania wiedzy z zakresu oceny tych emisyjności w danych warunkach eksploatacji oraz narzędzi umożliwiających

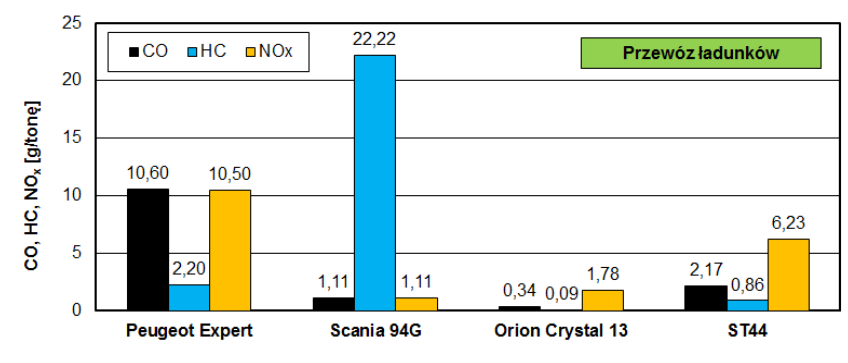

Rys. 7. Porównanie emisji toksycznych składników spalin przypadającej na jedną tonę ładunku podczas 1-godzinnego użytkowania pojazdów drogowych i szynowych

Fig. 7 - Comparison of toxic exhaust emissions per one ton of cargo during 1 hour of operation of the road and rail vehicles

\section{CONCLUSIONS}

Driving tests (actual traffic conditions/operation) are the most desirable method for the ecological assessment of vehicles, because only they can provide the actual values of emissions from vehicles. Type approval measurement (certification) of mass transport vehicles carried out on engine dynos provide information about the engine's emissions, but unfortunately, they do not provide any information about the real emissions and fuel consumption in actual driving conditions on the road [4]. The use of mobile gas analyzers resulted in increased interest in measurements of emissions in actual driving conditions, especially for heavy-duty and utility vehicles [1]. Analysis and performed studies, as well as global trends in the field of ecology, show that in order to effectively reduce environmental pollution it is necessary to measure the emission of toxic exhaust gases in real driving conditions.

As described above vehicle emission road tests in real driving conditions are more favorable from the vehicle ecological operation viewpoint. They allow the measurement of harmful substances emissions in different conditions, and not only in strictly defined circumstances, as it is in the case of stationary type approval tests. This gives designers more information about the direction in which they should further develop vehicles to optimize the ecological properties of their combustion engines.

Testing vehicles in real traffic conditions is made possible thanks to modern test apparatus. This apparatus must be compact, to be able to fit and install it in a vehicle. It must also be versatile to be able to measure the concentrations of harmful substances in exhaust gases of vehicles for mass transport of various kinds and also different approval categories.

Due to the pronounced technological progress in the field of measurement of exhaust emissions in real driving conditions, both in terms of compliance of vehicles with regard to the type-approval and the level of emission of vehicles already in operation, there is 
porównanie dotychczasowych metod pomiarowych $\mathrm{z}$ metodami pomiarów prowadzonych w warunkach rzeczywistych.

\section{Bibliografia}

[1] Gao Y., Checkel M.D.: Emission factors analysis for multiple vehicles using an on-board, in-use emissions measurement system. SAE Technical Paper Series 2007-01-1327.

[2] Marciniak Z., Stawecki W., Merkisz J., Pielecha I., Pielecha J.: Możliwości modyfikacji taboru spalinowego

w celu zmniejszenia jego oddziaływania na środowisko naturalne. Technika Transportu Szynowego, nr 3, 2011, s. 43-48.

[3] Marciniak Z., Stawecki W., Pielecha I., Pielecha J.: Ekologiczne aspekty spalinowych pojazdów szynowych eksploatowanych na krajowych liniach kolejowych. Logistyka, nr 4, 2010.

[4] Merkisz J., Pielecha J.: Analysis of Particle Concentrations and Smoke in Common-Rail Diesel Engine. SAE Technical Paper Series 2008-01-1743.

[5] Merkisz J., Pielecha J.: Emissions and Fuel Consumption during Road Test from Diesel and Hybrid Buses under Real Road Conditions. IEEE Vehicle Power and Propulsion Conference (VPPC'10), Lille 1-3.09.2010, CD, s. 1-6.

[6] Merkisz J., Pielecha J., Gis. W.: Exhaust Emission Results from Light Duty Diesel in a Road Tests. Automobiles and Sustainable Mobility, FISITA 2010 World Automotive Congress, F2010-A-045. Scientific Society for Mechanical Engineering (GTE). Budapeszt 30.05-4.06.2010, p. 1-10.

[7] Merkisz J., Pielecha J., Radzimirski S.: New Trends in Emission Control in the European Union. Springer Tracts on Transportation and Traffic, Vol. 1, 2014.

[8] Pielecha I. Marciniak Z.: Wpływ silników spalinowych pojazdów trakcyjnych eksploatowanych w kraju na środowisko - próby i badania oraz wytyczne dla redukcji emisji składników szkodliwych. Pojazdy Szynowe, $n r$ 1, 2009, s. 34-43.

[9] Walsh M.: Global trends in motor vehicle pollution control: a 2011 update. Combustion Engines, No.2/2011(145) 